\title{
Le cerf-volant aux îles Kiribati : un hybride oiseau- pirogue
}

Note de recherche

\section{Anne Di Piazza}

\section{OpenEdition}

\section{Journals}

\section{Édition électronique}

URL : https://journals.openedition.org/tc/432

DOI : $10.4000 /$ tc. 432

ISSN : $1952-420 X$

\section{Éditeur}

Éditions de l'EHESS

Édition imprimée

Date de publication : 1 octobre 1998

ISSN : 0248-6016

\section{Référence électronique}

Anne Di Piazza, «Le cerf-volant aux îles Kiribati : un hybride oiseau-pirogue », Techniques \& Culture [En ligne], 30 | 1998, mis en ligne le 28 octobre 2005, consulté le 29 septembre 2022. URL : http:// journals.openedition.org/tc/432 ; DOI : https://doi.org/10.4000/tc.432

Ce document a été généré automatiquement le 29 septembre 2022.

Tous droits réservés 
Le cerf-volant aux îles Kiribati : un hybride oiseau-pirogue

Note de recherche

Anne Di Piazza 